\title{
Osmia species (Hymenoptera, Megachilidae) from the southeastern United States with modified facial hairs: taxonomy, host plants, and conservation status
}

\author{
Molly G. Rightmyer ${ }^{1, \dagger}$, Mark Deyrup ${ }^{2, \ddagger}$, John S. Ascher ${ }^{3, \S}$, Terry Griswold ${ }^{1,1}$ \\ I USDA-ARS Bee Biology and Systematics Laboratory, BNR 244 UMC 5310, Utah State University, Logan, \\ UT 84322-5310 2 Archbold Biological Station, P.O. Box 2057, Lake Placid, FL 338623 American Museum of \\ Natural History, Division of Invertebrate Zoology, Central Park West at 79th Street, New York, NY 10024-5192 \\ † urn:lsid:zoobank.org:author:90A04B61-0B07-4F3F-8F9E-DDCBDC108314 \\ ¥urn:lsid:zoobank.org:author:98A484A3-EBC4-490E-BA1D-658BA45BBD84 \\ § urn:lsid:zoobank.org:author:AD099E58-A69A-4C05-8E8E-2CC367FF3CAO \\ | urn:lsid:zoobank.org:author:80DCC2BA-6D2D-449B-83DA-08BB71DBE589 \\ Corresponding author: Molly G. Rightmyer(molly_rightmyer@yahoo.com)
}

Academic editor: Michael Engel | Received 10 May 2011 | Accepted 1 July 2011 | Published 21 November 2011

urn:lsid:zoobank.org:pub:8DBFAD71-1C0C-4B82-8C06-1BCEAD9D85C6

Citation: Rightmyer MG, Deyrup M, Ascher JS, Griswold T (2011) Osmia species (Hymenoptera, Megachilidae) from the southeastern United States with modified facial hairs: taxonomy, host plants, and conservation status. In: Engel MS (Ed) Contributions Celebrating Kumar Krishna. ZooKeys 148: 257-278. doi: 10.3897/zookeys.148.1497

\begin{abstract}
We describe females and males of Osmia (Melanosmia) calaminthae sp. n., an apparent floral specialist on Calamintha ashei (Lamiaceae), and provide observations on the behavior of female bees on flowers of this plant. We also provide diagnostic information for Osmia (Diceratosmia) conjunctoides Robertson, stat. n., and synonymize $O$. (Diceratosmia) subfasciata miamiensis Mitchell with $O$. conjunctoides syn. n. Females of both O. calaminthae and O. conjunctoides are unique among North American Osmia for having short, erect, simple facial hairs, which are apparent adaptations for collecting pollen from nototribic flowers. Osmia calaminthae is currently only known from sandy scrub at four nearby sites in the southern Lake Wales Ridge in Highlands County, Florida, USA, while O. conjunctoides is known from limited but widespread sites in the southeastern USA. We discuss the conservation status of both species based on known or speculated floral associates and distributions.
\end{abstract}

Copyright Molly G. Rightmyer et al. This is an open access article distributed under the terms of the Creative Commons Attribution License, which permits unrestricted use, distribution, and reproduction in any medium, provided the original author and source are credited. 


\section{Keywords}

Bee, Apoidea, Megachilinae, Osmiini, Melanosmia, Osmia calaminthae, Osmia conjunctoides, Lamiaceae, Calamintha ashei, oligolecty

\section{Introduction}

The genus Osmia in North America comprises about 150 described species (Ascher and Pickering 2011) that are usually metallic green or blue, sometimes brilliantly so. The 30 species recorded east of the Mississippi River prior to this contribution have been relatively well studied taxonomically (Sandhouse 1939, Mitchell 1962), and the internet houses freely available matrix-based and dichotomous keys to the species (Arduser 2009, Griswold et al. 2010, Andrus et al. 2010). As in many other bee genera, the species diversity in eastern North America is depauperate compared to west of the Mississippi River. Nonetheless, there remain many areas in eastern North America that would benefit from increased study and collection effort. In particular, Florida and other states in the southeastern United States appear to house a number of interesting bee endemics, and new state records continue to be documented from this region (Hall and Ascher 2010).

Herein we describe one such find, Osmia (Melanosmia) calaminthae sp. n., known only from Highlands County, Florida, in sandy scrub at the southern end of the Lake Wales Ridge. This habitat houses many Florida endemic plants and animals, including bees (Deyrup et al. 2002). Osmia calaminthae is apparently a floral specialist on Calamintha ashei (Weath.) Shinners (Lamiaceae), Ashe's Calamint (Figs 1, 4; also known as Ashe's Savory), a threatened woody mint found in sand pine/scrub habitat in the Florida central highlands and southeastern Georgia (Coile 2000). The new species was discovered by Deyrup et al. (2002) during surveys of the Archbold Biological Station. During subsequent searches by J. S. Ascher, H. G. Hall, and colleagues, including photographer T. Lethbridge, numerous females and a few males were found visiting the host plant in late morning at the Placid Lakes Development southwest of the town of Lake Placid (N27.250, W81.389). At this site the host plant grows commonly in sand scrub, much of which occurs in vacant lots within a partially completed housing subdivision.

Osmia calaminthae females have modified hairs on the face that readily distinguish the species from similar species of Osmia (see Diagnosis, below). Modified facial hairs for collecting pollen from nototribic flowers occur rarely in scattered species across multiple bee families (e.g., Müller 1996, Ayala and Griswold 2005, Michener 2007). In O. calaminthae, the hairs on the frons, clypeus, and scape are uniformly short, erect, and simple, and apparently function to trap pollen when the female enters the corolla and her head contacts the anthers of this flower (Figs 2, 3, 5-7). The pollen accumulates to form a conspicuous mass and evidently remains on the face of the bee for an extended time during foraging bouts (as opposed to being immediately transferred 
to the metasomal scopa), as evidenced by conspicuous loads adhering to the face of approximately one-fourth of the female specimens examined. Interestingly, another Osmia that is also found in the southeastern United States, Osmia (Diceratosmia) conjunctoides Robertson, new status, has nearly identical hairs on the frons and clypeus of females (Fig. 8). Osmia (Diceratosmia) subfasciata miamiensis Mitchell, 1962, was described as a subspecies but is herein distinguished from typical O. subfasciata subfasciata Cresson and newly synonymized under O. conjunctoides. Specimens and floral records are scarce for $O$. conjunctoides (Pascarella 2008); only one examined specimen has an associated floral record, Crotalaria pumila Ortega (Fabaceae), which limits our interpretation of floral associations for this bee.

It is the honor of MGR and JSA to dedicate this paper to Kumar Krishna in celebration of his lifelong achievements in the study of Isoptera. Both authors are grateful to Kumar and Valerie Krishna for the kindness and generosity shown to them during their respective tenures at the American Museum of Natural History.

\section{Methods}

The morphological terminology follows that proposed by Michener (2007) and Harris (1979). Mandibular teeth are numbered from ventral-most tooth to dorsal-most tooth. Thus, the ventral-most tooth is the first tooth and the next ventral-most tooth is the second. In the species treated herein, between the second and dorsal-most tooth is a smaller, slightly more interior, cutting edge extended from the dorsal-most tooth, here called the third tooth. The dorsal-most tooth is the fourth tooth.

The following morphological abbreviations are used: flagellar segment (F), metasomal tergum (T), metasomal sternum (S), and ocellar diameter (OD). Measurements are given for the holotype specimen, with the observed range from other specimens following in parentheses.

Bee specimens were examined and measured using a Leica MZ12 dissection microscope and ocular micrometer. Pollen grains were slide mounted in silicone oil and examined using a Nikon E200 compound microscope. Photomicrographs of pinned specimens were taken using a Keyence VHX-500F Digital Imaging System.

The following abbreviations are used for specimen repositories, with individuals associated with those repositories following in parentheses:

Champaign - Illinois Natural History Survey, Champaign IL (D. Dmitriev)

New York - American Museum of Natural History, New York NY (J. S. Ascher, J. G. Rozen, Jr.)

Gainesville - Florida State Collection of Arthropods, Gainesville FL (J. Wiley)

Lake Placid - Archbold Biological Station, Lake Placid FL (M. Deyrup)

Logan - USDA-ARS Bee Biology and Systematics Laboratory, Logan UT (T. Griswold, H. Ikerd)

Orlando - University of Central Florida, Orlando FL (S. M. Fullerton, S. Kelly) 
Raleigh - North Carolina State University, Raleigh NC (R. Blinn)

Washington, D.C. - United States National Museum of Natural History, Washington D.C. (S. G. Brady, B. Harris)

\section{Taxonomy}

Osmia (Melanosmia) calaminthae, Rightmyer, Ascher \& Griswold, sp. n. urn:Isid:zoobank.org:act:DB373E46-E362-4108-8AD5-52DE1598A8FD http://species-id.net/wiki/Osmia_calaminthae

Figs 2, 3, 5-7, 9-26

Osmia sp.; Deyrup et al. 2002: 99.

Diagnosis. Females of $O$. calaminthae are most similar to $O$. (Melanosmia) albiventris Cresson and $O$. (Melanosmia) cordata Robertson, sharing with those species the white hairs of the body (including scopa) and four-toothed mandible with the outer and condylar ridges parallel (Figs 13, 14). Unlike those species, O. calaminthae has specialized hairs on the face (including clypeus and frons) that are extremely short, evenly spaced, simple, and stout (Figs 5, 6; longer and finer in O. albiventris and O. cordata). In addition, the punctures of the head and mesosoma are large and deeply impressed in $O$. calaminthae, the hairs on the posterior surface of the foretarsal segments are relatively long, the wings are heavily infuscate, the rugose sculpturing of the dorsal propodeal triangle is strongly impressed and well differentiated from the ventral area of shagreened integument (Fig. 15), and the hairs on the lateral dorsal surface of T1 are dense and long, much more so than on remaining metasomal terga (Figs 9, 10; T1 hairs not conspicuously longer and denser than those on other metasomal terga in $O$. albiventris and O. cordata). Osmia (Melanosmia) sandhouseae Mitchell is a superficially similar species found sympatrically in Florida and is known to visit Calamintha in March (Deyrup et al. 2002); however, in that species the outer and condylar ridges of the mandible converge apically (parallel in O. calaminthae) and the hairs of the clypeus and frons are long and fine.

Males of $O$. calaminthae are distinguished from many other Osmia by the relatively slender, pointed teeth of $\mathrm{T} 7$ (basally about one-fourth the width of the midapical emargination; Fig. 22). Among the Osmia with such slender teeth on T7, O. calaminthae is extremely similar to $O$. cordata due to the white hairs on the metasomal terga (including laterally on T6) and S4 (Fig. 24), and by the hairs on the apical margin of S4 that are longer medially than laterally. Osmia calaminthae can be separated from $O$. cordata by the deep and large punctures on the frons and vertex. Males of $O$. sandhouseae Mitchell are superficially similar; however, in that species the punctures on the upper gena are extremely large and deep, much more so than on the vertex, while in $O$. calaminthae the punctures of the upper gena and vertex are subequal in size. 


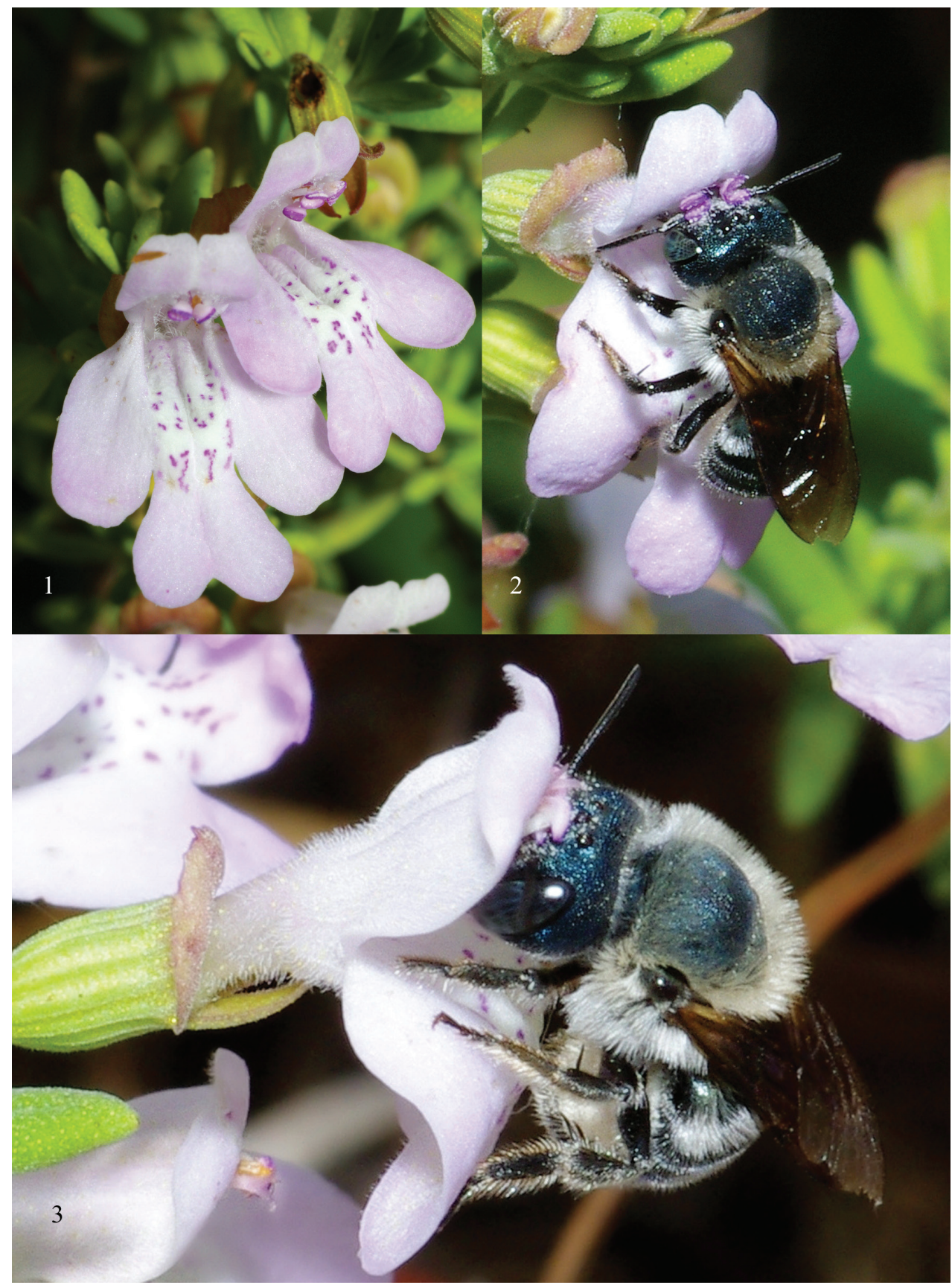

Figures I-3. I Flowers of Calamintha ashei (Weath.) Shinners (Lamiaceae) 2-3 Osmia calaminthae, sp. n., visiting flowers of $C$. ashei at Lake Placid, Highlands County, Florida. Photographs by T. Lethbridge. 


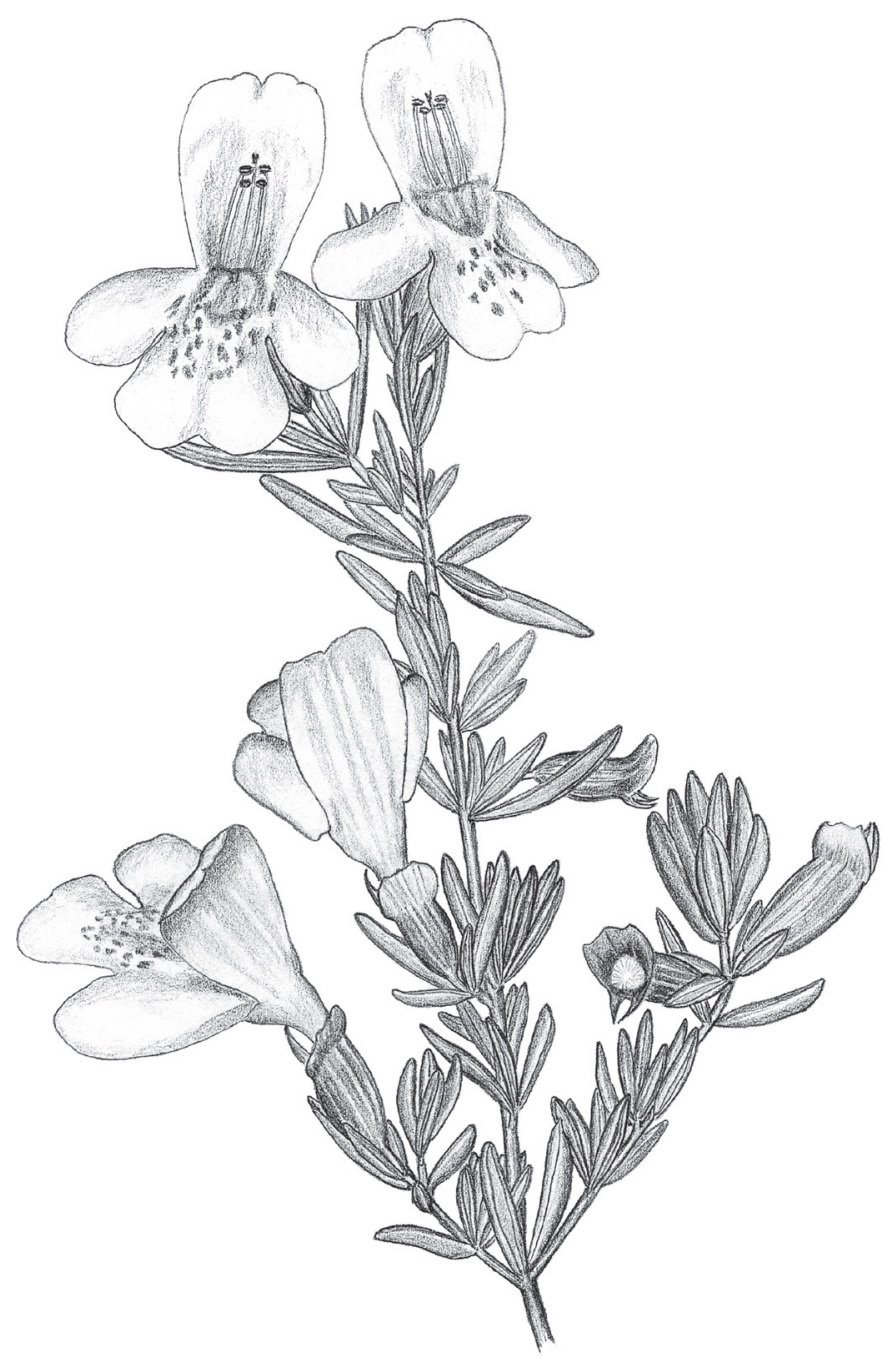

Figure 4. Habitus illustration of Calamintha ashei, the only known floral host of Osmia calaminthae sp. n. Illustration by M. Deyrup.

Description. Female. Figs 5-7, 9-16. Total length: ca. $11 \mathrm{~mm}(10-11 \mathrm{~mm})$; Forewing length: $7 \mathrm{~mm}(6-7 \mathrm{~mm})$; distance between lateral ocellus and preoccipital margin $0.6 \mathrm{~mm}(0.5-0.6 \mathrm{~mm})$; distance of lateral ocellus to compound eye $0.6 \mathrm{~mm}$.

Color: Dark blue (mesosoma sometimes with integument slightly paler blue), except with brown integument on mouthparts, labrum, mandible, apical edge of clypeus, antenna, legs distal to trochanters, apical margins of metasomal terga, and metasomal sterna. Wings strongly infuscate.

Pubescence: Hairs entirely white to pale golden except darker golden on mouthparts and distally on legs, brown on wings; hairs conspicuous on mesosoma and T1 


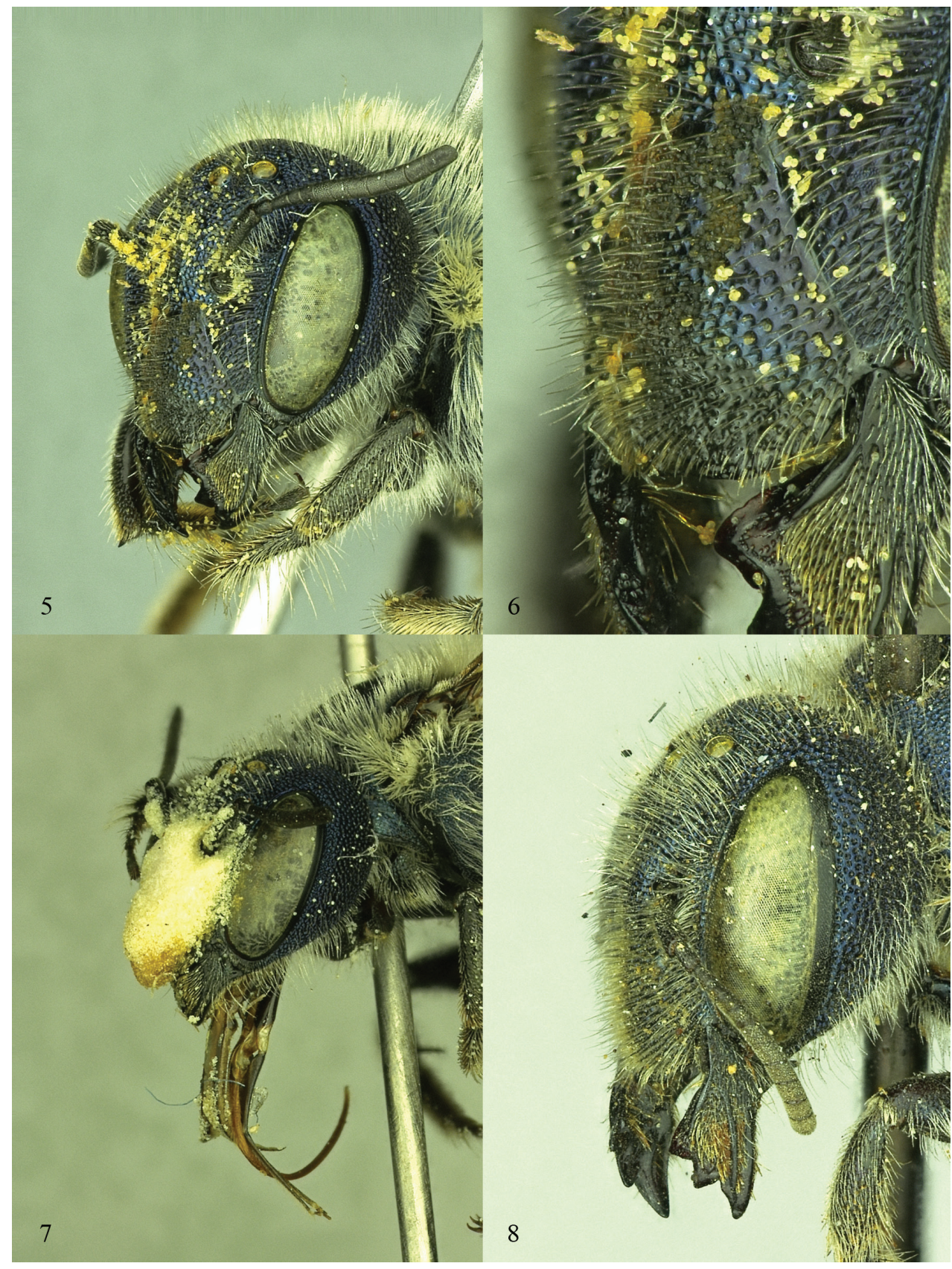

Figures 5-8. Oblique view of female Osmia heads 5, 6 Osmia calaminthae, holotype specimen 6 Close up of clypeus and paraocular area $\mathbf{7}$ Osmia calaminthae, paratype specimen, showing pollen mass on face 8 Osmia conjunctoides (holotype specimen of $O$. subfasciata miamiensis). 
so as to obscure underlying blue integument, but inconspicuous on distal terga. Galea and basal two labial palpal segments with hairs on lateral margins straight, $0.2-0.5$ $\mathrm{OD}$ in length. Labrum with long hairs arranged in two curved, transverse rows, along subapical margin and at approximate midpoint (hairs slightly more scattered along row at midpoint), with additional fringe of shorter hairs at apical margin. Clypeus below apical margin with lateral tuft of pale golden, medially directed hairs (often hidden by clypeal margin). Head with short, stout, simple, erect hairs evenly spaced on face (Figs 5, 6), scape, and pedicel, these hairs denser and appressed on outer surface of mandible, longer and relatively sparse on ventral margin of mandible, vertex, and posteriorly on gena. Hypostomal area with straight, minutely branched hairs evenly distributed across area, 2.0-3.0 OD in length. Mesosoma (excluding legs and wings) and laterally on T1 covered with dense, long, minutely branched, white hairs (Figs 9, 10); remainder of metasomal terga with hairs conspicuously shorter and sparser than hairs on mesosoma and T1. Legs with hairs on outer surfaces white, on forefemur and foretibia relatively slender and minutely branched, on foretarsal segments long (ca. 3.0 OD in length), slightly stouter, and simple; on midleg outer surface entirely minutely branched; on hindleg outer surface mostly minutely branched except basitarsus with hairs appressed, simple, and relatively stout. Legs with hairs on inner surfaces of fore- and midfemora and fore- and midtibiae white, minutely branched, and relatively sparse, with some shining areas lacking hairs; inner surface of hindfemur with denser, minutely branched white hairs, of hind tibia with very dense, short, white, subappressed hairs; inner surfaces of all tarsal segments with hairs dense, golden, stout, and simple. Wing membranes with short, dense, evenly distributed, simple hairs. Scopa white to pale golden.

Punctation: Head and mesosoma with punctures nearly contiguous, round, and strongly impressed except as follows: labrum mostly impunctate; clypeus with impunctate midapical truncation about half length of F1; clypeus immediately adjacent to apical impunctate truncation and next to compound eye with punctures relatively small and dense (Fig. 12); paraocular area with punctures separated by up to two puncture diameters; clypeus, vertex, and mesoscutum immediately posterior to median longitudinal sulcus with punctures separated by up to one puncture diameter; mesepisternum in upper anterior corner with punctures relatively small, ventrally with punctures separated by up to one puncture diameter; hypostomal area, pronotum, propodeum, and legs with punctures shallowly impressed, sometimes elongated into oval shape; tegula with punctures minute, dense at margins and sparse medially (separated by up to four or five puncture diameters); metanotum, metepisternum, and lateral and posterior surfaces of propodeum with background integument moderately granulose and relatively dull; propodeal triangle with dorsal third strongly, deeply areolate to lineate, lower two thirds granulose grading to shining, glabrous area along lower lateral margin (Fig. 15). T1 anterior and dorsal surfaces, and T2-T3 shining, T4-T6 moderately shagreened, T1 medially on disc with small punctures separated by up to a puncture diameter, grading to slightly larger and denser punctures on more posterior terga, T1-T5 apical impunctate bands relatively 


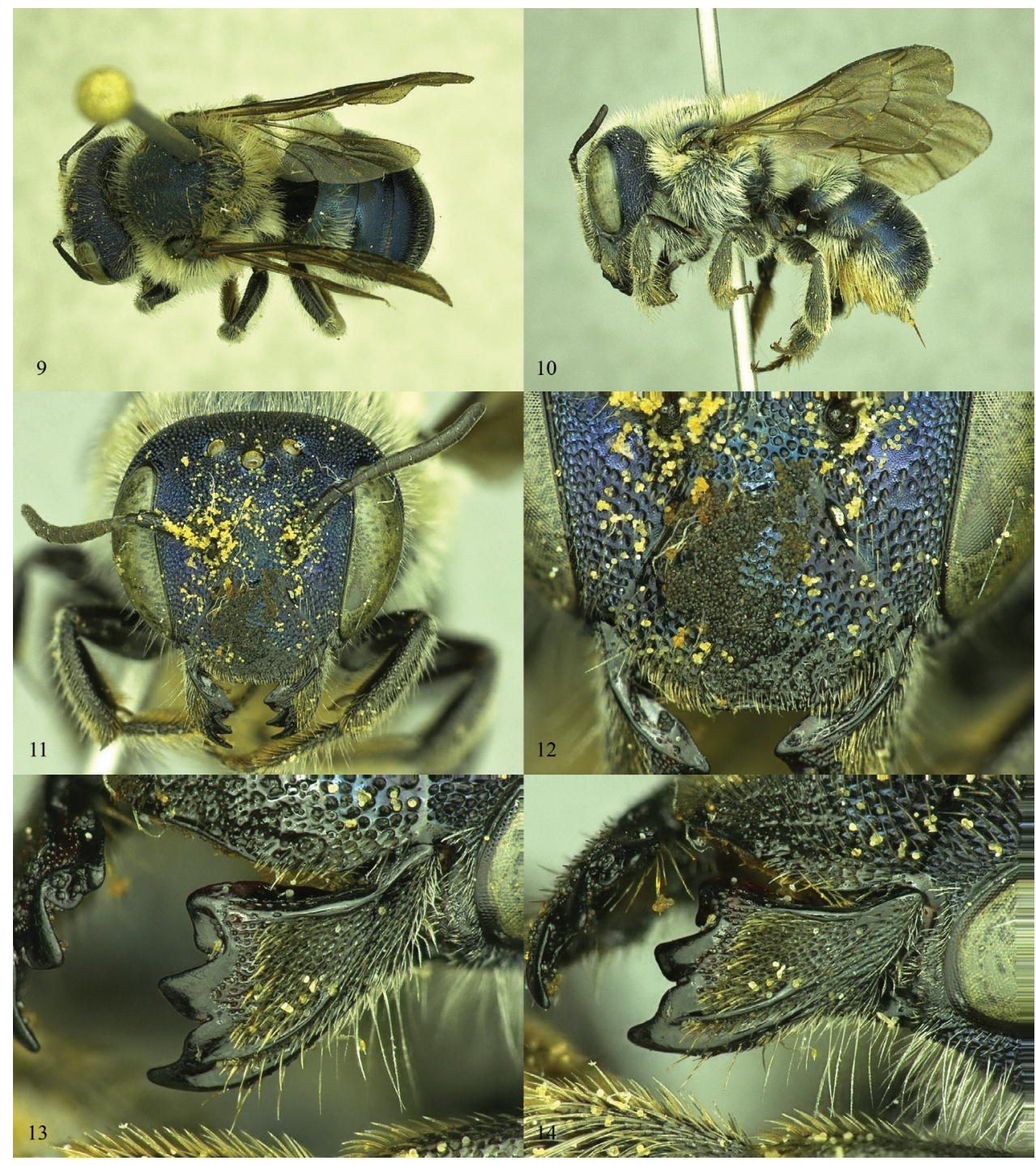

Figures 9-I4. Osmia calaminthae, holotype female 9 Dorsal habitus I 0 Lateral habitus I I Face $\mathbf{2}$ Close up of clypeus and paraocular area 13 Mandible, showing the shape and placement of teeth 14 Mandible, showing outer and condylar ridges and overall shape.

narrow laterally, ca. one puncture diameter in length, medially with impunctate bands widened, up to four puncture diameters in length (or even longer at exact midpoint).

Structure: Labial palpus four-segmented, second labial palpal segment ca. onefourth longer than basal-most segment. Mandible with outer and condylar ridges of subequal thickness or with condylar ridge slightly thicker, parallel along length (Fig. 14); apical margin with four teeth, third separated from second and fourth by carina, margin of third tooth forming distinct $\mathrm{V}$-shape with adjacent margin of second and 
weakly curved U-shape with adjacent margin of fourth, third tooth weakly set back from second and fourth (Fig. 13); inner, ventral margin of mandible lacking distinct tooth, very weakly diverging away from condylar ridge basally; mandible apically widened (1.5 times wider than median width), first tooth length subequal to that of other teeth or very slightly longer, second tooth located about half way between first and fourth teeth (Fig. 13). Clypeus with apical margin forming anteriorly produced truncation, linear or weakly concave along truncation and forming ca. 130 degree angle with lateral apical margin of clypeus. F1 one-third longer than F2 length or slightly more, remaining apical flagellar segments gradually increasing in length such that F10 ca. one-fourth longer than F1 length. Vertex behind lateral ocellus 2.5-3.0 OD in length. Genal width subequal to that of compound eye in lateral view. Preoccipital margin rounded, not carinate. Hypostomal carina moderately high, highest at about midpoint of hypostomal area posterior to angle, not forming triangular projection at this point but forming distinct, semicircular projection, tapering to low carina or near obsolescence at angle. Malus forming pointed apical spine, this spine more or less a narrowed continuation of nearby edge of velum. Foretarsal segments excluding basitarsal and apical-most segments with lobes moderately swollen, anterior lobes slightly longer than posterior. Midtarsal segments with anterior and posterior lobes of equal width, weakly swollen; hind tarsal segments not swollen. Hind tibial spurs more or less straight on basal three-fourths, with outer spur moderately curved at apical tip and inner spur slightly less strongly curved apically, outer spur about a fifth to a sixth shorter than inner. Hind basitarsus with lateral margins of outer surface parallel.

Male. Figs 17-26. Total length: ca. $10 \mathrm{~mm}$; Forewing length: $6 \mathrm{~mm}$; length of lateral ocellus to preoccipital margin $0.4 \mathrm{~mm}$; length of lateral ocellus to compound eye $0.5 \mathrm{~mm}$.

Color: Head and mesosoma pale blue, metasoma dark blue, except with brown integument on mouthparts, labrum, mandible, apical edge of clypeus, antenna, legs distal to trochanters, S5-S8, and apical margins of all metasomal terga and S1-S4. Wings moderately infuscate, except along leading edge of forewing more strongly infuscate.

Pubescence: White, minutely branched hairs on body except golden to pale golden, stouter hairs on inner surfaces of tarsi. Labrum sparsely covered with hairs on apical half and with hairs forming short fringe at apical margin. S2 with hairs at apical third relatively long (ca. 3.0 OD). S3 with dense, posteriorly directed hairs forming semicircular fringe along entire emargination (hairs ca. 1.5 OD in length throughout) (Fig. 23). $\$ 4$ sparsely covered with white, medio-posteriorly directed, distally wavy hairs, these hairs not interrupted medially on S4, distinctly longer at midapical truncation than laterally on apical margin of disc. S6 midapical truncation sparsely covered with short, white hairs.

Punctation: Head with punctures ovate to circular, contiguous or nearly so and deeply impressed except as follows: labrum mostly impunctate on basal half; clypeus with impunctate area immediately next to anterior tentorial pit and impunctate band along apical margin about one-fourth length of F1 and slightly swollen on median third (Fig. 20); disc of clypeus and interantennal area with punctures small and ovate; 


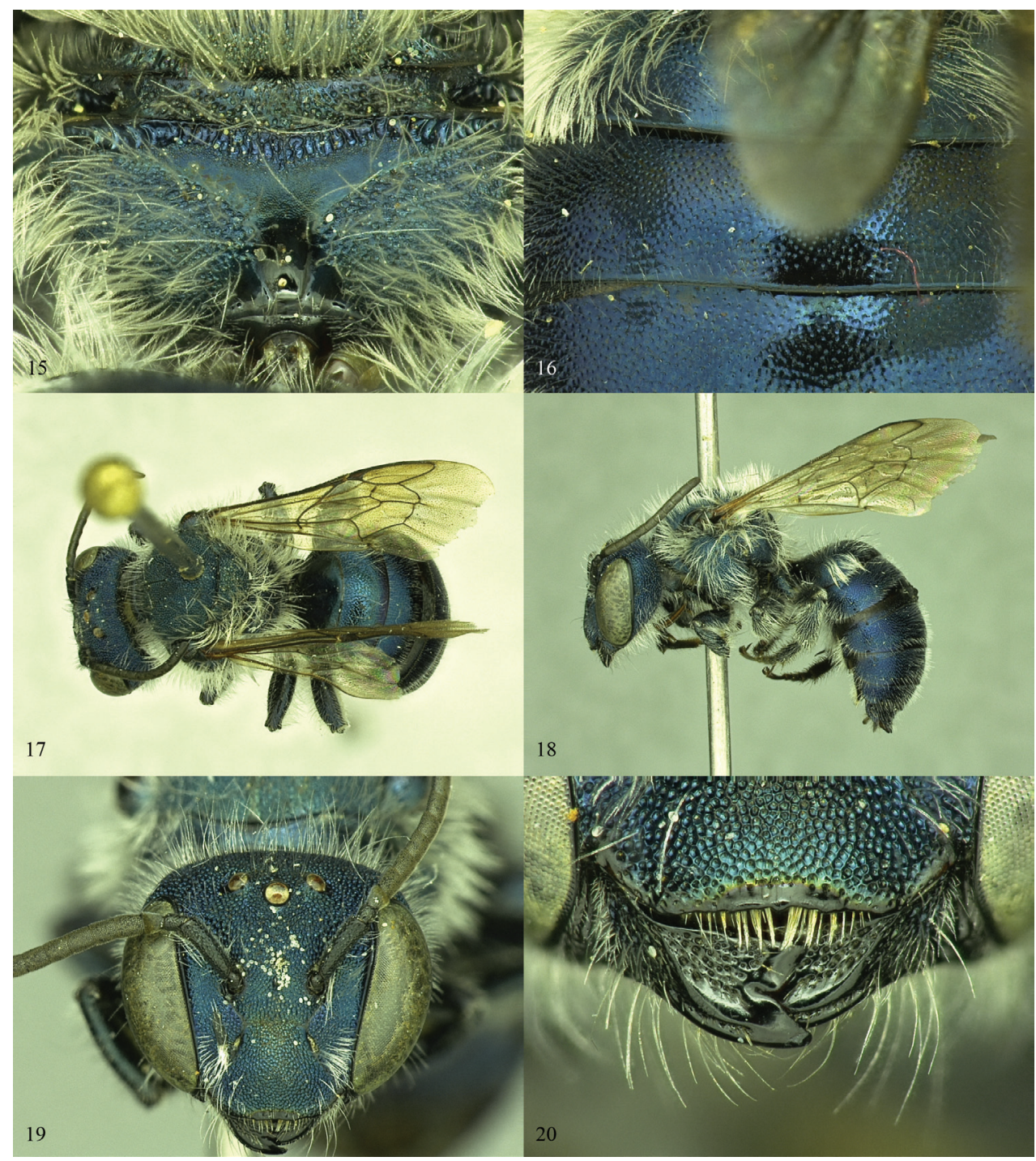

Figures I5-20. 15, 16 Osmia calaminthae, females 15 Propodeal triangle of paratype specimen 16 T1T3 of holotype specimen 17-20 Osmia calaminthae, male paratype 17 Dorsal habitus 18 Lateral habitus 19 Face 20 Mandibles

hypostomal area anteriorly near angle with punctures weakly, shallowly impressed. Mesosoma with punctures round, nearly contiguous and deeply impressed except as follows: tegula with punctures minute, sparser medially, separated by up to eight puncture diameters; metepisternum with punctures more irregular and with impunctate area near anterior margin and sometimes medially across sclerite; pronotum and lateral and posterior surfaces of propodeum strongly shagreened, with very weakly, shallowly impressed punctures; metanotum with punctures distinct but smaller than on 
mesoscutum and separated by about a puncture diameter; propodeal triangle strongly lineolate to reticulate on dorsal half and shagreened on lower half, sometimes with weakly shining areas laterally near ventral margin (Fig. 21); legs with inner surfaces of trochanters, femora, and tibiae (except hind tibia) shining, with scattered smaller punctures. T1 with anterior surface weakly shagreened, shining; metasomal terga with dorsal surfaces very weakly shagreened, shining. Metasomal terga with punctures small and well impressed (slightly less impressed on T5-T7). T1-T4 dorsal surfaces with punctures separated between 0.5 and 2.0 puncture diameters; apical impunctate margins medially ca. 3.0-4.0 puncture diameters in length, laterally as little as 1.0 puncture diameter. T5-T6 with punctures less distinct, separated by ca. 1.0 puncture diameter medially; T5 with apical impunctate margin medially ca. 3.0 puncture diameters in length. S1-S3 with punctures moderately impressed, ovate. S4 with integument punctate basally, grading to shagreened and papillate at bases of hairs apically. S5-S6 shagreened.

Structure: Mandible with outer and condylar ridges converging apically; with two teeth, upper and lower teeth nearly the same width and length; inner margins of upper and lower teeth forming nearly 90 degree angle; upper tooth with inner and dorsal margins forming ca. 45-60 degree angle; inner, ventral margin of mandible weakly diverging away from condylar ridge basally. Clypeus apical margin lacking distinct apical truncation, medially very weakly concave, laterally with weakly tuberculate swelling. Flagellar segments subequal in length, except F1 about three-fourths length of F2 and F11 slightly longer than other segments. Vertex behind lateral ocellus 1.5 OD in length or slightly longer. Genal width ca. three-fourths that of compound eye in lateral view or slightly wider. Preoccipital margin rounded, not carinate. Hypostomal carina relatively shallow, about the same height along length of head, gradually tapering to near obsolescence at angle, not forming distinct tooth. Malus forming small but distinct, pointed apical spine. Foretarsal segments excluding basitarsal and apical-most segments with anterior lobes very slightly more swollen than posterior. Mid-and hind tarsal segments not swollen. Hind tibial spurs relatively stout, very weakly curved along length, outer spur slightly shorter than inner. Hind basitarsus with lateral margins of outer surface subparallel, with very small tooth on inner margin about one-fourth from apical margin along length. T6 midapically with moderate emargination, forming onehalf of circle in outline or nearly so (Fig. 22); T6 lateroapical margin smoothly, weakly convex, not forming distinct tooth or forming very weak lateral tooth. T7 midapically strongly emarginate, forming semicircle about as wide as deep (slightly smaller than 1.0 OD in width), with spines on either side of emargination slender, about one-fourth as wide as emargination width (Fig. 22). S2 evenly convex, covering most of S3 (in one specimen with weak emargination at midapex). $S 3$ with midapical emargination strongly semicircular, about as wide and long (half entire width of sternum, 1.5 OD in length or slightly more, measuring only apical margin of sternum and not including basal fringe of hairs; Fig. 23). S4 midapically with wide, poorly defined truncation (about third width of entire sternum). S6 with midapical truncation ca. one-fifth width of sternum, truncation as wide as long, apical margin of truncation distinctly emargin- 


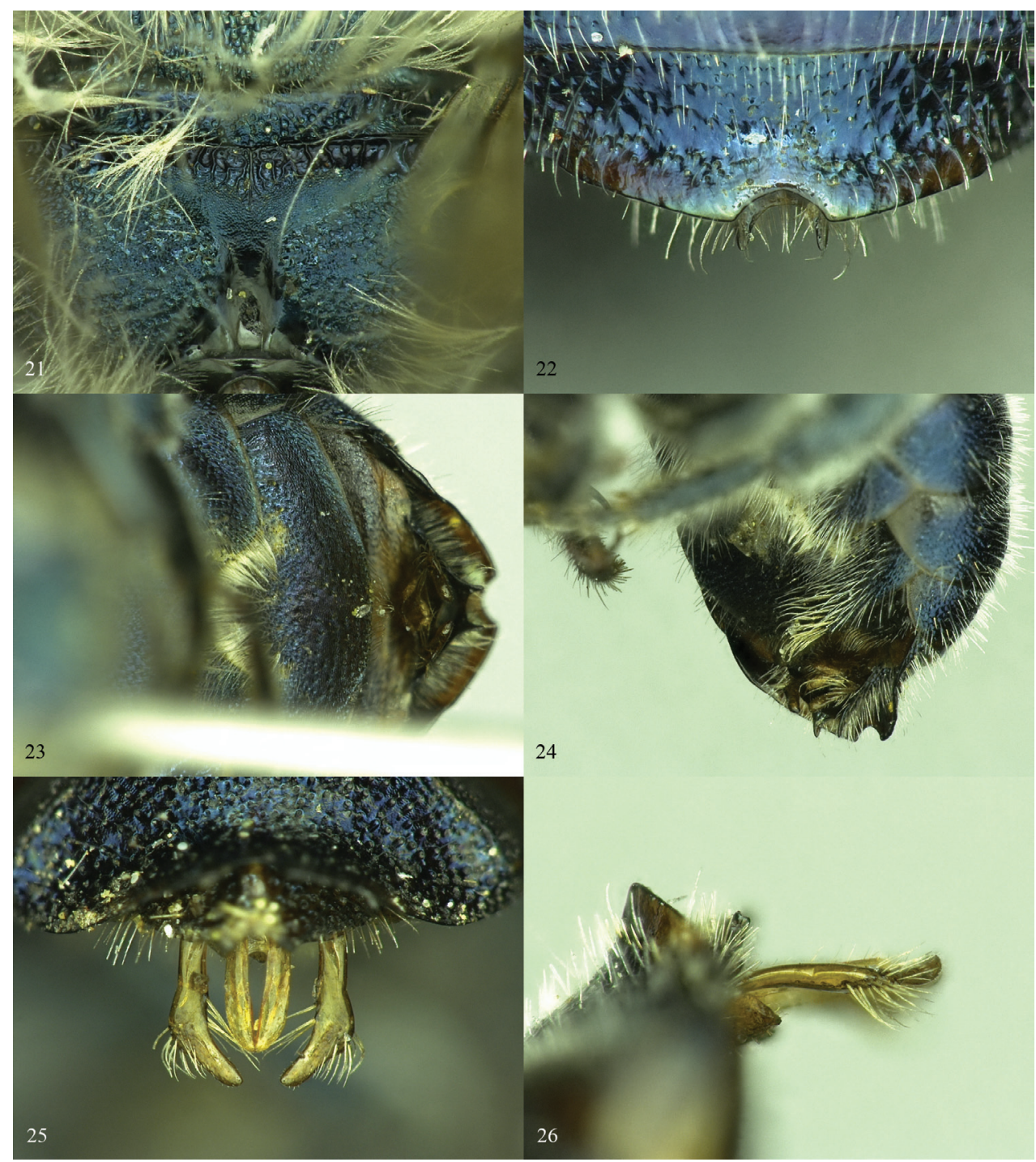

Figures 21-26. Osmia calaminthae, male paratypes 2 I Propodeal triangle 22 T6 and T7 23 S3 and S4, dorsal view 24 S3 and S4, oblique view 25 Genital capsule, dorsal view 26 Genital capsule, lateral view.

ate. Gonoforceps narrowed apical to subapical bend, weakly pointed at apical tip in dorsal view (Fig. 25), more or less straight along length in lateral view (Fig. 26).

Distribution. Known only from Highlands County, Florida.

Holotype female. "USA: FL [Florida]: Highlands Co. Lake Placid, 18 March 2002, J. S. Ascher, ex: Calamintha ashei//HOLOTYPE $q$ Osmia calaminthae Rightmyer, Ascher, Griswold [red label]" (New York). The type locality is southwest of the town of Lake Placid in an area of the subdivision of Placid Lakes Development that still includes many vacant lots: N27.2502, W81.3898. 
Paratypes. USA: FLORIDA, Highlands Co., Lake Placid, 18 March 2002, Calamintha ashei, J. S. Ascher (4ㅇ, New York; 1ㅇ, Logan), Archbold Biological Station, 28 March 1988, Satureja ashei, A. Warneke (1 9 , Lake Placid), 29 March 2000, C. ashei, M. Deyrup (1 + , Lake Placid), 10 April 2001, C. ashei, M. Deyrup (1q, LaKe Placid), 18 April 1983, H. L. Dozier (1 9 , Gainesville), 25 April 1983, Lupinus diffusus, A. Schreffler (1 + , Gainesville), Archbold Biological Station, Junction roads 40 \& 36 Rosemary Bald, 27 March 2001, C. ashei, M. Deyrup (2+, Lake Placid); Lake Wales Ridge Wildlife and Environmental Area, Gould Road Preserve, N27.13657, W08132495, 15 March 2009, Ceratiola scrub, Townes and bowl traps, M. \& N. Deyrup, A. May, H. Otte (4, Lake Placid; i + , Logan); Lake Wales Ridge Wildlife and Environmental Area, Holmes Avenue Preserve, N27.28097 W081.31862, 24 April 2009, C. ashei, M. Deyrup (19, Lake Placid); Placid Lakes, 8 April 2001, C. ashei, Florida scrub habitat, M. Deyrup (3ㅇ, Lake Placid); Placid Lakes Development, 16 March 2002, C. ashei, sand pine scrub habitat, M. Deyrup (3․ Gainesville; 4ㅇ, Lake Placid; i 9 , Logan), 29 March 2007, C. ashei, M. Deyrup (2+, Lake Placid), 30 March 2009, C. ashei, J. S. Ascher, D. Webber (3ㅇ, 20, New York), 31 March 2009, C. ashei, J. S. Ascher, D. Webber (8+, New York), 3 April 2006, C. ashei, J. S. Ascher, C. Dong ( 4 , New York), 4 April 2006 (8ㅇ, New York; 1ㅇ, Logan).

Additional records. Four females were collected by H. G. Hall at the type locality on 31 March and others were observed and photographed there by T. Lethbridge on 31 March and 2 Apr 2010 (Figs 1-3; additional photos and informative captions here: http://bugguide.net/node/view/394002/bgimage).

Etymology. The name "calaminthae" is Latin, referring to mint, and is derived from the name of its presumed pollen host plant.

\section{Osmia (Diceratosmia) conjunctoides Robertson, stat. n.}

http://species-id.net/wiki/Osmia_conjunctoides

Figs $8,27-32$

Osmia conjunctoides Robertson 1893: 276; Sandhouse 1939: 140 [synonymy with $O$. subfasciata]; Mitchell, 1962:83 [synonymy with O. subfasciata subfasciata]; LaBerge (in Webb) 1980: 118 [lectotype designation].

Diceratosmia subfasciata conjunctoides (Robertson); Michener 1949: 264 [diagnosis]. Osmia (Diceratosmia) subfasciata miamiensis Mitchell 1962: 84. syn. n.

Diagnosis. Females of this species are distinguished from all other Diceratosmia, including typical Osmia (Diceratosmia) subfasciata, by the nearly uniformly short, straight to slightly hooked hairs on the clypeus and slightly longer hairs on the frons (Fig. 8). Osmia conjunctoides is also distinguished from $O$. subfasciata by the scopal hairs: in $O$. conjunctoides, the apical tips of the hairs on $\mathrm{S} 2$ and $\mathrm{S} 3$ are weakly tapered, while in $O$. subfasciata the hairs are blunt, widened and slightly rounded at their apical tips. The form of clypeal hairs in the female is very similar to that of $O$. (Melanosmia) calamin- 


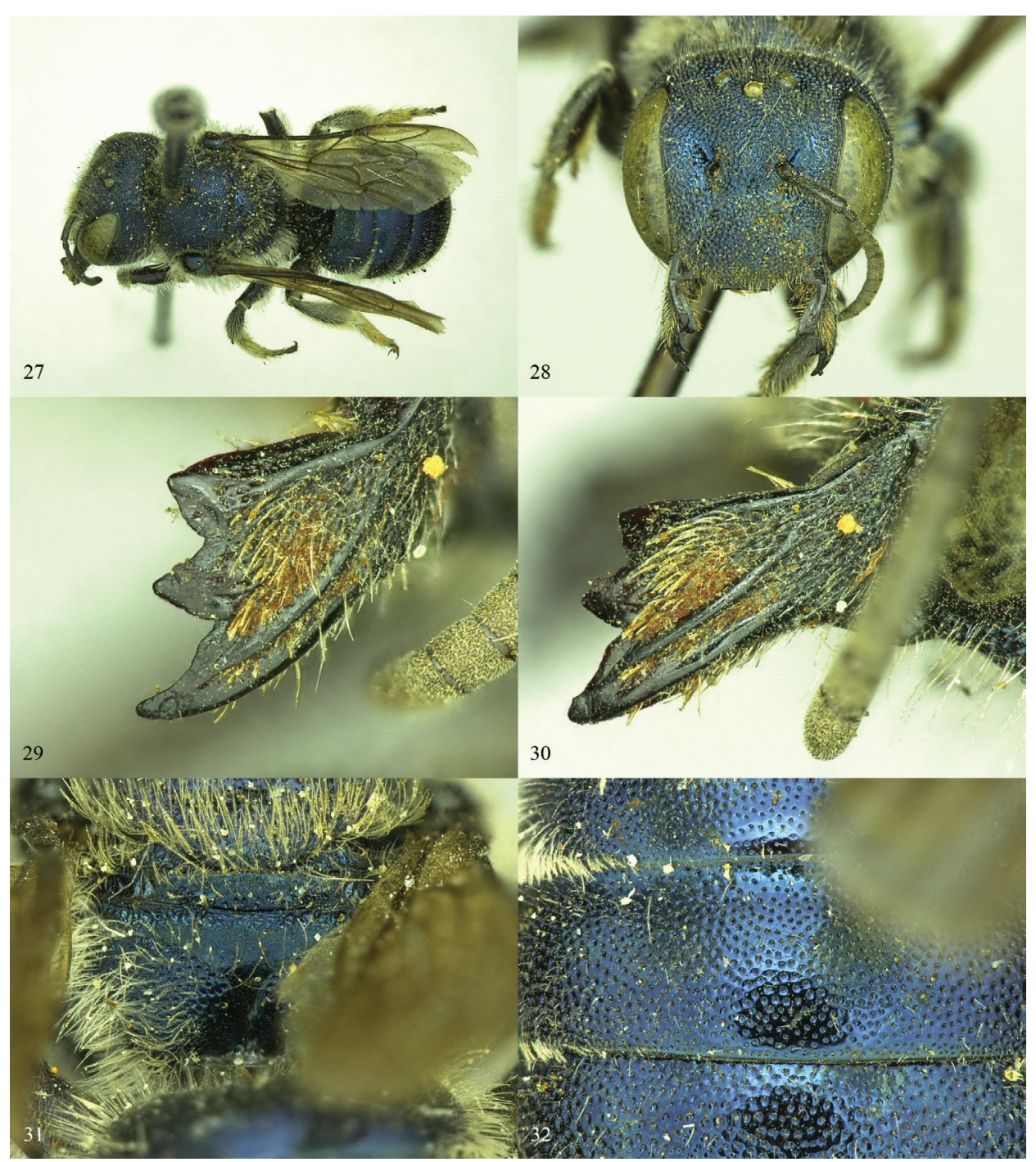

Figures 27-32. Osmia conjunctoides (female holotype of $O$. subfasciata miamiensis) 27 Dorsal view. 28 Face 29 Mandible, showing the shape and placement of teeth $\mathbf{3 0}$ Mandible, showing outer and condylar ridges and overall shape $\mathbf{3}$ I Propodeal triangle $\mathbf{3 2}$ T1-T3.

thae; however, in that species the punctures of the metasomal terga are not so large (compare Figs 16 and 32), there is no carinate ridge on the hind coxa, the parapsidal line is punctiform, and the metasomal terga (especially T1 and T2) lack the distinct, short, dense, pale, apicolateral hair bands characteristic of subgenus Diceratosmia (in O. calaminthae $\mathrm{T} 1$ has dense, pale hairs, but these hairs are long and contrast with the short, sparse hairs on T2).

Males of $O$. conjunctoides are extremely similar to $O$. (Diceratosmia) subfasciata. Finding reliable characters to distinguish the two species is made problematic by the 
availability of only seven male specimens of $O$. conjunctoides. This material suffices to permit the two species to be differentiated by the following characters: In $O$. conjunctoides, the mesoscutum is more finely and densely punctate than in O. subfasciata $(O$. conjunctoides with ca. 16 punctures between parapsidal line and midline, these punctures distinctly smaller than those on the scutellum; $O$. subfasciata with ca. 11 punctures between parapsidal line and midline, these punctures about the same size as those on the scutellum). In dorsal view, T1 of $O$. conjunctoides is less concave along its anterior margin, while in O. subfasciata the anterior margin is strongly curved, forming anterolaterally rounded corners. In addition, $O$. conjunctoides is usually a slightly larger bee than O. subfasciata (6-7 mm vs. 8-9 $\mathrm{mm}$ ); all examined $O$. conjunctoides from Florida and Georgia are dark blue, while all examined $O$. subfasciata from throughout its range are a paler greenish blue; however, the male specimen of $O$. conjunctoides from Mississippi is greenish blue, similar to $O$. subfasciata. In O. conjunctoides, the lower propodeal triangle tends to be weakly shagreened throughout, while in $O$. subfasciata the lower propodeal triangle tends to be shining. In addition, T6 of $O$. conjunctoides has an apical, upturned flange that is longer than in examined specimens of $O$. subfasciata (ca. 2.0 adjacent puncture diameters in the former versus 1.0 adjacent puncture diameters in the latter).

Material examined. USA: FLORIDA, Citrus Co., Inverness, Robertson [ $1 \sigma^{\hat{\sigma}}$, New York], 17 February 1891 [1 $\hat{0}$, Champaign (holotype of O. conjunctoides)]; Highlands Co., Highlands Hammock State Park, 14 April 1968, malaise trap, H. V. Weems Jr. [1웅 Gainesville]; Hillsborough Co., Lutz, 17 March 1926, Krautwurm [19, Logan]; Liberty Co., Torreya Ravine, 15 April 1938, F. E. Lutz (1옹 New York); Miami-Dade Co., Cape Florida, 15 February 1925, Crotolaria, S. Graenicher [1일 Washington DC (holotype of O. subfasciata miamiensis)]; Miami Beach,

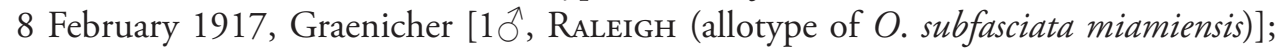
Seminole Co., Lower Wekiva River Preserve State Park, Burn Zone LW-10, S39 T19S R29E, LLP-Turkey Oak, P. Russell, S. Fullerton, 6 February 2001, blue pan trap (1ठ,

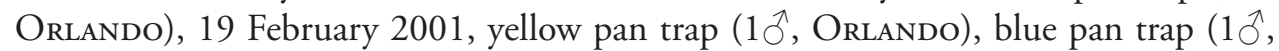
Logan); GEORGIA, St. Catherines Island, 16-22 April 1983, Rozen, Favreau, Stupakoff (1, New York); MISSISSIPPI, Forrest Co., Hattiesburg, 12 March 1944, C. D. Michener (1 $\overbrace{}^{\top}$, New York), 6 April 1944 (1 $q$, New York).

Comments. Graenicher (1930) provides brief collecting notes on this species, under the name $O$. subfasciata: "This species occurs in the sand dunes at Miami Beach and on Biscayne Key (across the Bay southeast of Miami), and visits the flowers of Crotalaria pumila. Dates of capture: February 8, 15, and March 17."

Michener (1949: 264) considered a male specimen of $O$. conjunctoides from northern peninsular Florida to intergrade with the typical O. subfasciata in features of T6 and T7 (although not in color). However, he was apparently unaware of the distinct facial and scopal hair features distinguishing females of $O$. conjunctoides from $O$. subfasciata. Specimens of $O$. conjunctoides that we have examined from northern peninsular Florida as well as Mississippi and Georgia are consistent with those from southern Florida in these diagnostic features of the females as well as in the finer punctures of the male mesoscutum. Although O. conjunctoides and $O$. subfasciata sensu stricto are extremely similar in the male $S 4$, we do not agree 
with the historic placements of this bee as a subspecies or synonym of $O$. subfasciata due to the consistent differences in male punctation and female clypeal and scopal hairs.

According to Mitchell (1962: 84), two additional female paratype specimens of $O$. subfasciata miamiensis exist in Raleigh with the same label data as the male allotype. Pascarella (2008) also recorded the species from "Charlotte Harbor," possibly based on distributional records found in Michener (1949), but we have not been able to confirm this record. Until we have access to further material, O. conjunctoides is provisionally considered to range from southern Florida north to Georgia and Mississippi, while we can confirm the presence of typical O. subfasciata from northeastern Mexico and southeastern California southeast to Alabama and South Carolina, and northeast to Illinois and New Jersey.

\section{Natural history and conservation status}

\section{Osmia calaminthae}

As indicated by its specific epithet, $O$. calaminthae appears to be closely associated with the woody mint Calamintha ashei (Figs 1, 4). Individual plants of this species may persist for at least a decade, possibly considerably longer. The flowering period is primarily from mid-March through mid-April; there can be variation in flowering phenology within this main blooming period among individuals growing in close proximity. Individual mature plants present hundreds of flowers over a period of several weeks. For flower visitors, $C$. ashei provides a dependable annual resource, even when the population of mature plants is small; as few as 20-30 plants may produce thousands of flowers each season.

Flowers have a corolla about $7 \mathrm{~mm}$ long, strongly protected against nectar-robbers by a stiff calyx that subsequently functions as a seed capsule (Figs 1, 4). There is almost no evidence of nectar robbing. Pollen is produced by four anthers whose filaments lie along the fused upper petals. Anthers are arranged in two rows, approximately marking the corners of a square (Fig. 1). In late morning and early afternoon when the anthers open, visiting female O. calaminthae rapidly bob their heads three to four times upon entering a flower (Figs 2, 3). This behavior, unusual in bees, might be associated with dislodging pollen, although this remains to be investigated. Pollen grains scraped from the head of one paratype specimen of $O$. calaminthae were found to be consistent with those described for Calamintha: three ridges were observed in lateral view, suggesting a hexacolpate condition (Trudel and Morton 1991). The behavior exhibited by $O$. calaminthae has not been observed in 23 other species of bees that visit flowers of $C$. ashei (Deyrup et al. 2002). Approximately one-fourth of the examined females had a large quantity of pollen trapped on the clypeus, supraclypeal area, frons, and scape (i.e., with pollen masses conspicuously visible to the naked eye, similar to Fig. 7). The large pollen load on the face suggests that females of O. calaminthae do not immediately groom the pollen back to the scopa when foraging between flowers. Such large pollen masses may even indicate that females are able to use the modified hairs on the face, in addition to the metasomal scopa which also contained pollen, to transport pollen to the nest; however, this was not directly observed and should be investigated in the future. 
Flowers of $C$. ashei are also visited by flies in the family Bombyliidae: Bombylius spp., Systoechus solitus (Walker), Geron sp. and Toxophora sp., as well as a member of the Syrphidae: Copestylum florida (Hull). The occurrence of numerous alternative potential pollinators adds some resilience to a pollination system that includes a rare plant and an apparently specialized bee. The only species of visitor that occurs in large enough numbers to be suspected of being a disruptive competitor in some patches of $C$. ashei is the European Honey Bee, Apis mellifera Linnaeus.

The known distribution and natural history of $O$. calaminthae suggest that it may be among the most geographically restricted and host specific bees in eastern North America. It is possible that $O$. calaminthae has wider geographic and host plant ranges than now known, as there has never been a comprehensive attempt to survey the bees of Florida, or to document their hosts. There are, however, biogeographic factors that could explain narrow geographic and host ranges for this species.

Osmia calaminthae is known from Florida scrub habitat on the southern half of the Lake Wales Ridge. Florida scrub is a unique shrub community found on ridges and knolls of wind-deposited silica sand. Vegetation consists of small, sclerophyllous oaks and a variety of other shrubs and small trees. The low and open structure of the habitat is maintained by occasional fires. For a more complete description of Florida scrub, see Myers (1990). An important sub-category of Florida scrub habitat is the "scrub rosemary bald." Scrub Rosemary, Ceratiola ericoides Michx. (also known as Sandhill- or Florida-Rosemary, or Sand Heath), is an aberrant member of the Ericaceae that occurs on the most highly drained scrub sites, often forming nearly pure stands of bushes that grow to be about $1.5 \mathrm{~m}$ high, with patches of bare sand between the clumps of Ce. ericoides (Johnson 1982). Calamintha ashei and several other narrowly distributed Florida scrub specialist plants seem to need bare sand patches in scrub rosemary balds, although some of these plants can move into areas of bare sand caused by human disturbance. Several of the plants found in rosemary balds have host-specific insects, including $C$. ashei, which is the host of the plant bug Keltonia clinopodii Kelton (Miridae) (Kelton 1966). Palynological evidence shows that Ceratiola barrens were much more widespread in south Florida at various times during the last 40,000 years (Delcourt and Delcourt 1981, Trapnell et al. 2007).

The Lake Wales Ridge, especially its southern half where O. calaminthae occurs, is the area with the largest number of Florida scrub specialist arthropods and plants, and has the only concentration of scrub specialists not found elsewhere in Florida (Deyrup 1990). This is probably due to the large size of the Lake Wales Ridge, its relative antiquity (over one million years), its southern position, and its uneven topography, which may affect fire frequency (Deyrup 1990). About 90 species of Florida scrub specialist arthropods are known from the Lake Wales Ridge, although many of these also occur in scrub areas elsewhere in Florida (Deyrup 2011, unpublished list). Calamintha ashei is largely restricted to the Lake Wales Ridge (Turner et al. 2006). Another spring-blooming woody mint, Conradina brevifolia Shinners, has a similar floral structure, although it is yet to be associated with $O$. calaminthae. Conradina brevifolia is largely restricted to a small area on the Lake Wales Ridge (Turner et al. 2006). 
Osmia calaminthae is currently known from only four sites within an area about 20 $\mathrm{km}$ long and $2 \mathrm{~km}$ wide on the Lake Wales Ridge. Archbold Biological Station is a private research station on the southern end of the Lake Wales Ridge where natural habitats have been protected since 1941. Two other protected sites are Lake Wales Ridge Wildlife and Environmental Areas managed by the Florida Fish and Wildlife Conservation Commission. One of these areas, Gould Road Preserve, has a large population of $C$. ashei and apparently a substantial population of $O$. calaminthae, but the site is unfenced and subject to pesticide drift from adjacent orange groves. The other protected site, Holmes Avenue Preserve, also has a large population of C. ashei, but is similarly unfenced, includes a large number of small, unacquired private parcels, and is subject to destructive use by off-road vehicles. There are over 20 Florida scrub preserves on the Lake Wales Ridge, but many of these lack large populations of $C$. ashei. The majority of $O$. calaminthae records are from scattered undeveloped lots in Placid Lakes, a platted subdivision south of the town of Lake Placid; this collection area is unprotected.

The nest site of $O$. calaminthae is unknown, but nest sites are less likely to be a limiting factor for this species than a scarcity of floral hosts and habitat. If nests are in dead wood, fires that remove most dead wood could affect populations of $O$. calaminthae.

Considering all the factors discussed above, attention should be given to the conservation needs of this recently discovered bee. The type locality of this species, where most known individuals have been observed, photographed, and collected, is a site with many vacant lots within a subdivision. Future full residential development at this site would threaten much of the known habitat of this species. Osmia calaminthae, remains, however, an extremely poorly known insect. It has a short flight period, and is therefore easily overlooked. It could be more abundant and widespread than it appears at present. Surveys of additional potential habitat, i.e., areas of sand scrub where the host plant occurs, are urgently needed to better assess whether the few known sites are critical habitat for the species or if it is more widely distributed but under recorded.

\section{Osmia conjunctoides}

Unfortunately, O. conjunctoides has been too rarely collected to allow for more than a few speculative comments on its conservation status; none of the authors have seen this bee in life. Only one examined specimen, the holotype of $O$. subfasciata miamiensis, has a recorded host plant associated with it (Crotalaria pumila Ortega); thus, it is not possible to say if the species is restricted in its plant host use. However, the presence of nearly uniformly short, erect hairs on the face of females is rare among Osmia in North America; in fact, this particular facial hair morphology is only known from $O$. conjunctoides and $O$. calaminthae. It is therefore reasonable to suspect that $O$. conjunctoides is associated with a restricted set of floral host species or with a particular floral morphology. At least six other Osmia from North America have facial hair modifications suggestive of pollen collection from nototribic flowers (V. H. Gonzalez, Griswold, \& Rightmyer, unpublished data); the hairs on these bees either form a basket of stiff, proclinate hairs on the vertex and frons, or are cork-screw shaped on the clypeus and frons. Although the 
hair morphology is not identical, the placement of the modified hairs on the clypeus and frons appears to be associated with pollen collection from nototribic flowers in both Old and New World Osmia, usually from the family Lamiaceae (although polylecty with preference for both Lamiaceae and Fabaceae has been documented; Müller 1996) or Scrophulariaceae.

A strong association of $O$. conjunctoides with Crotalaria pumila is tenuous. This legume has anthers that are enclosed in a narrow passageway in the keel, and it is not yet known if a bee collecting pollen or nectar would contact the anthers of this plant with her head. However, in alfalfa (Medicago sativa Linnaeus), another plant in the family Fabaceae (albeit an unusual one), the act of pollination changes the placement of the anthers from a ventral position to a more dorsal one (i.e., "tripping" the flower, causing the staminal column to snap upward toward the banner petal; Pitts-Singer and Cane 2011). Indeed, for M. sativa, Megachile rotundata (Fabricius) is preferred over honey bees for managed pollination due to its tolerance for being struck repeatedly on the head by the anthers of this flower. Thus, although Crotolaria is not likely the main host plant of $O$. conjunctoides, it cannot be ruled out until field observations have taken place. It is also unknown if the distribution of $C r$. pumila has any predictive value for the distribution of $O$. conjunctoides. However, as it is the only floral information available to us for $O$. conjunctoides we provide a few comments on the natural history of this plant species and a related species within the same genus. Crotalaria pumila occurs in beach dunes and coastal pinelands along the Atlantic Coast from Brevard County south (Taylor 1998). Although much of this range has been heavily developed or overrun by exotic plants, patches of native habitat can be found in a series of coastal preserves, the largest of which are Jonathan Dickinson State Park, Hobe Sound National Wildlife Preserve, and Merritt Island National Wildlife Preserve. Cape Florida, where the holotype of $O$. subfasciata miamiensis was collected, might still have a protected population of this species within Bill Baggs Cape Florida State Park. St. Catherines Island is a National Historic Landmark and is also a protected area. Crotalaria rotundifolia Walter ex J. F. Gmel. might also be a potential plant to investigate when searching for further specimens of $O$. conjunctoides; Cr. rotundifolia is more widespread in Florida, and inland populations are dependent upon fire. The most recently collected specimens were from a burn zone in Seminole County. Thus, open, frequently burned or disturbed areas (i.e., Brooksville Ridge in Citrus and Levy Counties) are potential habitat.

Until further individuals of $O$. conjunctoides have been located and studied, the conservation status of this species will remain unclear. It is potentially an endangered species, considering the massive scale of destruction and alteration of most of its presumed coastal habitat. The decrease of fire frequency in many inland areas of the southeastern United States may also be a factor in this species' conservation status, although the species has yet to be associated with a fire-dependent plant.

\section{Acknowledgements}

We are grateful to the individuals and institutions listed in Methods, above, for providing access to the material described herein. In addition, we thank David Wagner 
and Jane O'Donnell (University of Connecticut, Storrs, CT) for providing access to additional southeastern material of $O$. subfasciata. Specimen databasing for this study was supported by NSF-DBI\#0956388, Collaborative Research: Collaborative Databasing of North American Bee Collections within a Global Informatics Network. John S. Ascher is grateful to Robert G. Goelet for his generous support of bee research at the AMNH. Survey work on local bees and Florida scrub arthropods by M. Deyrup is supported by the Archbold Biological Station. Survey work on Lake Wales Ridge Wildlife and Environmental Areas was supported by the Florida Fish and Wildlife Commission as part of Florida's Wildlife Legacy Initiative and the U.S. Fish and Wildlife Service State Wildlife Grant T-15-D. We thank Tim Lethbridge for sharing his excellent photographs resulting from fieldwork focused on documenting the new species. Chaoyan Dong, H. Glenn Hall, and Dale Webber also assisted with fieldwork. Reviews by Michael Arduser, James H. Cane, Christophe Praz, and one anonymous reviewer are greatly appreciated. We thank Michael S. Engel for the invitation to contribute to this Festschrift.

\section{References}

Andrus R, Droege S, Griswold T, Pickering J (2010) Draft Guide to the Male Osmia of Eastern North America. http://www.discoverlife.org/mp/20q?guide=Osmia_male [accessed 6.XII.2010].

Arduser M (2009) Osmia of eastern North America (Females). http://pollinators.nbii.gov/documents/Arduser_keys/ENA\%20Osmia\%20key.pdf [accessed 6.XII.2010].

Ascher JS, Pickering J (2011) Discover Life bee species guide and world checklist (Hymenoptera: Apoidea: Anthophila). http://www.discoverlife.org/mp/20q?guide=Apoidea_species [Draft 28, accessed 24.III.2011]

Ayala R, Griswold T (2005) Nueva especie de abeja del género Osmia (Hymenoptera: Megachilidae) de México. Folia Entomologica Mexicana 44: 139-145.

Coile NC (2000) Notes on Florida's Regulated Plant Index (Rule 5B-40), Botany Contribution 38. Gainesville, Florida: Florida Department of Agriculture and Consumer Services, Division of Plant Industry.

Delcourt PA, Delcourt HR (1981) Vegetation maps for eastern North America: 40,000 yr. B.P. to the present. In: Romans RC (Ed) Geobotany II, Plenum Press, New York. 123-165.

Deyrup M (1990) Arthropod footprints in the sands of time. Florida Entomologist 73: 529538. doi: $10.2307 / 3495269$

Deyrup M, Edirisinghe J, Norden B (2002) The diversity and floral hosts of bees at the Archbold Biological Station, Florida (Hymenoptera: Apoidea). Insecta Mundi 16: 87-120.

Graenicher S (1930) Bee-fauna and vegetation of the Miami region of Florida. Annals of the Entomological Society of America 23: 153-174.

Griswold T, Ikerd H, Droege S, Pascarella JB, Pickering J (2010) Draft Guide to the Female Osmia of Eastern North America. http://www.discoverlife.org/mp/20q?guide=Osmia_female [accessed 6.XII.2010] 
Hall HG, Ascher JS (2010) Surveys of bees (Hymenoptera: Apoidea: Anthophila) in natural areas of Alachua County in north-central Florida. Florida Entomologist 93: 609-629. doi: 10.1653/024.093.0419

Harris RA (1979) A glossary of surface sculpturing. Occasional Papers in Entomology, State of California Department of Food and Agriculture 28: 1-31.

Johnson AF (1982) Some demographic characteristics of the Florida rosemary Ceratiola ericoides Michx. American Midland Naturalist 108: 170-173. doi: 10.2307/2425306

Kelton LA (1966) Two new species of Keltonia Knight, with a key to known species (Hemiptera: Miridae). Canadian Entomologist 98: 668-670. doi: 10.4039/Ent98668-6

Michener CD (1949) A revision of the American species of Diceratosmia (Hymenoptera, Megachilidae). Annals of the Entomological Society of America 42: 258-264.

Michener CD (2007) The Bees of the World, second edition. Johns Hopkins University Press, Baltimore, Maryland, xvi + [1] + 953 pp.

Mitchell TD (1962) The bees of the eastern United States. II. Technical Bulletin (North Carolina Agricultural Research Station) 152: 1-557.

Müller A (1996) Convergent evolution of morphological specializations in central European bee and honey wasp species as an adaptation to the uptake of pollen from nototribic flowers. Biological Journal of the Linnean Society 57: 235-252.

Myers RL (1990) Scrub and high pine. In: Myers RL, Ewel JJ (Eds) Ecosystems of Florida, University of Central Florida Press, Orlando, 150-193.

Pascarella JB (2008) The Bees of Florida. http://www.bio.georgiasouthern.edu/Bio-home/Pascarella/Intro.htm [accessed 28.III.2011]

Pitts-Singer TL, Cane JH (2011) The alfalfa leafcutting bee, Megachile rotundata: The world's most intensively managed solitary bee. Annual Review of Entomology 56: 221-237. doi: 10.1146/annurev-ento-120709-144836

Robertson C (1893) Notes on bees, with descriptions of new species. Transactions of the American Entomological Society 20: 273-276.

Sandhouse GA (1939) The North American bees of the genus Osmia. Memoirs of the Entomological Society of Washington 1: 1-167.

Taylor WK (1998) Florida wildflowers in their natural communities. University Press of Florida, Gainesville, Florida, xiv + 370 pp.

Trapnell DW, Schmdt JQ, Quintana-Ascencio PF, Hamrick JL (2007) Genetic insights into the biogeography of the southeastern North American endemic, Ceratiola ericoides (Empetraceae). Journal of Heredity 98: 587-593. doi: 10.1093/jhered/esm075

Trudel MCG, Morton JK (1991) Pollen morphology and taxonomy in North American Labiatae. Canadian Journal of Botany 70: 975-995. doi: 10.1139/b92-122

Turner WR, Wilcove DD, Swain HM (2006) State of the scrub: Conservation progress, management responsibilities, and land acquisition priorities for imperiled species of Florida's Lake Wales Ridge. Archbold Biological Station, Florida, iv + 160 pp.

Webb DW (1980) Primary insect types in the Illinois Natural History Survey Collection, exclusive of the Collembola and Thysanoptera. Illinois Natural History Survey Bulletin 32: 51-191. 